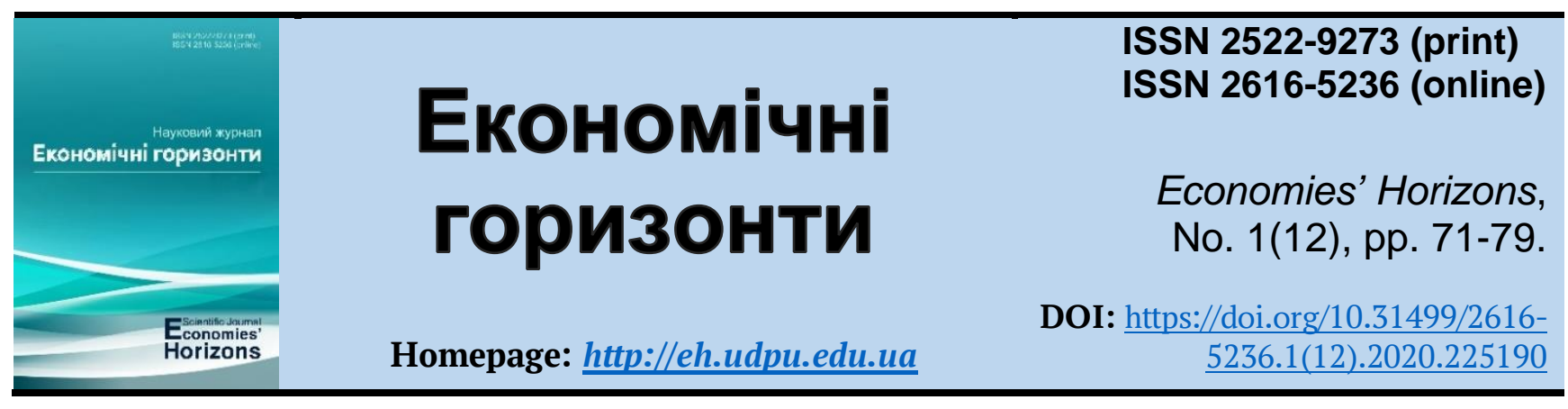

UDC 005.591.6:334]:[658.84:004.738.5]

\title{
Management decisions on modernization of e-commerce enterprises as subjects of innovative entrepreneurship
}

Received: 15 February 2020

Accepted: 17 March 2020

\author{
Volodymyr S. Symakov ${ }^{1}$
}

Symakov, V. S. (2020), "Management decisions on modernization of e-commerce enterprises as subjects of innovative entrepreneurship", Economies' Horizons, no. 1(12), pp. 71-79, doi: https://doi.org/10.31499/2616-5236.1(12).2020.225190

Abstract. The purpose of the article is to analyse the types of management decisions on the modernization of e-commerce enterprises as subjects of innovative entrepreneurship and to explore their content. Methodology. In the study of this issue used methods of generalization, comparison and systematic method. Results. In the article the types of management decisions on the modernization of ecommerce enterprises as subjects of innovative entrepreneurship are analysed. Their content has been studied. Scientific positions are described and statistical data on the research topic are given. Practical meaning. To better understand the issues of management decisions on modernization of e-commerce enterprises as subjects of innovative entrepreneurship, the author analysed foreign sources, which allowed to understand the features of world experience that determine the need of e-commerce enterprises in Ukraine to focus on new technological solutions and modern management approaches. Prospects for further research. The author analyses the current trends of enterprise modernization and notes that conversion optimization is becoming an increasingly serious problem in today's business environment, as companies seek to effectively customize the pages of their products and make sure that their products stand out in all areas of multi-channel marketing. This can include dynamic Facebook advertising, Google shopping advertising, or digital marketing efforts.

Keywords: management decisions, enterprises, e-commerce, innovative entrepreneurship, economics.

JEL Classification: D81, L81, O33.

Number of references: 22; number of tables: 0; number of figures: 1; number of formulas: $\mathbf{0 .}$

1 PJSC "Novokramatorsky engineering factory"; Head of the Finance Department; ORCID ID: https://orcid.org/0000-0003-1101-9383; e-mail: symakovv123@gmail.com. 


\section{Управлінські рішення щодо модернізації підприємств електронної комерції як суб'єктів інноваційного підприємництва}

\section{Володимир Сергійович Симаков ${ }^{1}$}

Стаття надійшла: 15.02 .2020

Стаття прийнята: 17.03.2020

\begin{abstract}
Symakov V. S. Management decisions on modernization of e-commerce enterprises as subjects of innovative entrepreneurship. Економічні горизонти. 2019. № 4(11). C. 71-79. DOI: 10.31499/2616-5236.1(12).2020.225190
\end{abstract}

Анотація. Метою статті є аналіз видів управлінських рішень щодо модернізації підприємств електронної комерції як суб'єктів інноваційного підприємництва та дослідити їх зміст. Методологія. При дослідженні даної проблематики використовувалися методи узагальнення, порівняння та систематичний метод. Результати. У статті проаналізовано види управлінських рішень щодо модернізації підприємств електронної комерції як суб'єктів інноваційного підприємництва. Досліджено їх зміст. Охарактеризовано наукові позиції та наведено статистичні дані по темі дослідження. Практичне значення. Для кращого розуміння проблематики управлінських рішень щодо модернізації підприємств електронної комерції як суб’єктів інноваційного підприємництва автором проаналізовано іноземні джерела, що дало змогу зрозуміти особливості світового досвіду, що визначають потребу підприємств електронної комерції України орієнтуватись впровадження новітніх технологічних рішень та сучасних управлінських підходів. Перспективи подальших досліджень. Автором проаналізовані сучасні тенденції модернізації підприємств та зазначається, що оптимізація конверсій стає усе більш серйозною проблемою в сучасному бізнессередовищі, оскільки компанії прагнуть ефективно налаштувати сторінки своїх продуктів і переконатися, що їх продукти виділяються по усіх напрямах багатоканального маркетингу. Це може включати динамічну рекламу в Facebook, рекламу покупок в Google або зусилля із цифрового маркетингу.

Ключові слова: управлінські рішення, підприємства, електронна комерція, інноваційне підприємництво, економіка.

Кількість джерел: 22; кількість таблиць: 0; кількість рисунків: 1; кількість формул: 0.

\section{Introduction.}

The way to increase the operational efficiency of e-commerce companies and their subsidiaries, providing production and supply of products, information infrastructure, etc., is provided, as world experience shows, through the implementation of the following management solutions: development of augmented reality, improves the consumer experience, leads to intensification of the process of purchasing products; growth of voice search volumes; the use of artificial intelligence, which helps stores learn more about customers; creating a personalized offer to provide an individual consumer experience; widespread use of chatbots in the process of interaction with consumers; widespread use of mobile technologies in the field of e-commerce; development and expansion of the list of online payment methods for goods and services; decentralized and artificial intelligence-driven e-commerce allows for faster implementation of innovations; the use of

1 ПрАТ «Новокраматорський машинобудівний завод»; начальник фінансового відділу; ідентифікатор ORCID: https://orcid.org/0000-0003-1101-9383; e-mail: symakovv123@gmail.com. 
service subscriptions and product information messages force customers to return to interaction with the e-commerce company; implementation of solutions in the field of environmental protection is an effective way to improve the management of e-commerce enterprises; e-commerce companies optimize digital conversion strategy.

\section{Literature review.}

Modernization of e-commerce enterprises as subjects of innovative entrepreneurship is important for today, which indicates the presence of scientific developments in this area. The efficiency of enterprises is due to the use of innovative types of employment aimed at providing them with highly qualified specialists with the required level of motivation to work. In particular, management decisions must have a lasting impact or at least bring us one step closer to a long-term goal. However, there are situations when it is difficult to link the decisions made and the results achieved. Numerous studies have addressed this aspect, for example: S. Kabaivanov and V. Markovska (2019), B. Molnár and D. Mattyasovszky-Philipp (2019), F. Malerba and M. McKelvey (2019), T. Semerádová and P. Weinlich (2019), I. Kuksa, I. Hnatenko, O. Orlova-Kurilova, N. Moisieieva and V. Rubezhanska (2019).

\section{Methodology.}

In the study of this issue used methods of generalization, comparison and systematic method.

\section{Research objectives.}

The purpose of the article is to analyze the types of management decisions on the modernization of e-commerce enterprises as subjects of innovative entrepreneurship and to explore their content.

\section{Results and discussions.}

Digital transformation trends are affecting everything from the supply chain to major business systems. The way to increase the operational efficiency of e-commerce enterprises and their dependent companies that provide production and supply of products, information infrastructure, etc., is provided, as world experience shows, through the implementation of the following management decisions:

1. The development of augmented reality, which enhances the sense of reality of online shopping and improves the consumer experience, leads to an intensification of the process of buying products.

Although fast delivery options have made online shopping almost as instantaneous as retail, there has historically been one drawback: you can't feel the product or see it on your body or at home. Augmented reality makes it possible to visualize the product. This technology helps online shoppers visualize the products they are interested in, whether they are clothing or furniture. Buyers can now see what they will look like when wearing a particular item of clothing, or what their home will look like with a certain colour of paint before clicking the "Buy" button (BigCommerce, 2020a). This helps online shoppers overcome the main barrier to online shopping because they can't see the product first hand, which takes shopping to the next level.

An example of a successful augmented reality experience in e-commerce is the experience of Burrow (2020), a DTC furniture brand that actively uses augmented reality to help customers imagine how their couches will fit in their living rooms. Burrow at Home software uses augmented reality to place realistic 3D models of Burrow sofas in photos taken on the client's iPhone and iPad.

In 2019, the research and consulting company Gartner predicted that by 2020, most consumers will make purchases using augmented reality (Omale, 2019).

Surveys show that in terms of augmented reality, $35 \%$ of respondents say that they shop online more often if they can virtually try a product before buying it, and $22 \%$ are less likely to visit a traditional offline store if augmented reality is available in their favourite 
online store (BigCommerce, 2020a). Augmented reality allows a person not only to see a 3D model of the product, but also allows the user to see what he looks like in a new outfit.

2. The growth of voice search.

People are increasingly relying on voice assistants such as Google Assistant or Amazon Alexa to do everything from checking the weather to buying goods online. According to Loop Ventures (Kinsella, 2019) by 2025, 75\% of households in the United States will have a smart speaker. This saves time when viewing, entering information about payment and delivery, the device remembers past purchases, which allows you to easily repeat the order.

As more households receive this technology and feel more comfortable using it for shopping, there is great untapped potential for this technology for e-commerce companies. An example of this is a study by Kensium (2020), which included the participation of voice solutions in the development of e-commerce through Amazon Alexa and Google Home in the list of 2020 trends that should be monitored.

3. Using artificial intelligence to help stores learn more about shoppers.

An important aspect of regular shopping that has historically been lost in online shopping is the store employee, who can offer product recommendations and individual recommendations based on the customer's needs or requests. At the same time, the prevalence of artificial intelligence and machine learning is growing as retailers focus on new ways to increase personalization and improve customer service. That is why some large online companies are investing significant resources in this development, which allows them to:

- get more opportunities to learn about their customers and give them the personalized experience they require;

- get more opportunities to link customer data with real-time information to improve the shopping process;

- get more opportunities to automate processes, such as customer support, with chatbots to help customers around the clock or generate timely offers;

- get more opportunities to optimize pricing, discounting and demand forecasting (BigCommerce, 2020a).

An example of a successful experience in this area is the Natori brand (2020), which used artificial intelligence to justify its costs for digital advertising. The result was an increase in income from social networks by $76 \%$.

4. Creating a personalized offer to provide an individual consumer experience.

One way to use artificial intelligence is to gather information about visitors and help adapt the website to its needs. At the same time, consumers especially value experiences and products that have been adapted to their needs. This is an experience that is often lost in the transition from traditional shopping to online self-service shopping. Studies show that the introduction of personalized experience has a significant impact on the income of ecommerce (growth of 25\%) (Abraham, Archacki, González, Fanfarillo and Van Kerckhove, 2020). Research also shows that personalization efforts can reduce failure rates by $45 \%$ (BigCommerce, 2020b).

Thus, the creation of a personalized offer is an important area, which, according to the author, can increase the competitiveness of ecommerce and strengthen its competitive position in the market, which increasingly requires an individual approach to interaction with the consumer. Such an individual approach should be harmoniously combined with decisions regarding the automation of processes, which should be extended as much as possible in those areas. Where personalized interaction is not fundamentally important and decisive for the consumer's decision to purchase.

5. Widespread use of chatbots in the process of interaction with consumers.

At the heart of personalization and artificial intelligence capabilities is a chatbot, which can act as a sales consultant and salesperson. Chatbots allow stores to communicate with thousands of customers, giving them a 
sense of personal attention and thoughtful recommendations based on their responses. According to research, an increasing number of shoppers prefer to communicate with bots and other digital self-service tools: more than $60 \%$ of customers said they do not mind websites, applications or chatbots responding to their simple requests (Osman, 2020). One of the main reasons for this response is the fast response time.

Experts predict that $80 \%$ of e-commerce companies will use chatbots in 2020 (Business Insider Intelligence, 2016). At the same time, chatbots are becoming more personalized to improve the quality of customer service.

6. Widespread use of mobile technologies in the field of e-commerce.

Traditionally, e-commerce has focused on bridging the gap and providing access to physical online stores. One of the obvious advantages of this approach is the ability to shop from anywhere in the world. Thus, according to Statista estimates, by the end of 2021, 73\% of e-commerce sales will be made on mobile devices (Loesche, 2018). With this in mind, ecommerce sites are increasingly being built using adaptive design, given that consumers need to be able to shop on their smartphones as easily as on their computers.

Another response to the ever-growing needs of users is the use of PWA or advanced web applications (BigCommerce, 2020e), which, in our opinion, can enable mobile shoppers to interact conveniently with online stores and provide e-commerce brands with another way to improve online customer engagement. using mobile devices.

7. Development and expansion of the list of methods of online payment for goods and services.

E-commerce companies do everything possible to ensure the convenience of users on e-commerce sites through a number of payment methods, including e-wallets. China is the leader in online payments in mobile applications, and WeChat and Alipay have more than 1 billion users (Semerádová and Weinlich, 2019, p. 80-89).

Customers are accustomed to shopping at large online stores such as Amazon and Walmart, which store information about customer bills and shipments, allowing you to place orders quickly and easily without a lot of data entry. E-commerce websites are increasingly using such payment methods as Apple Pay, Paypal and others, which provide seamless verification (Semerádová and Weinlich, 2019, p. 80-89; Enterprise Europe, 2018).

8. Decentralized and artificial intelligence-driven e-commerce allows for faster implementation of innovations.

So far, most of the trends in the list have been those with which the customer interacts directly. However, the technical structure of the online store also has a significant impact on customer experience and determines the development trends of e-commerce enterprises. Thus, decentralized management in e-commerce is a solution that allows you to completely separate the e-commerce platform of the store from the level of presentation of the web interface. This can allow e-commerce companies to use CMS, DXP, PWA or many other existing or custom interfaces, which can positively affect the performance of marketing, SEO and e-commerce business positioning (BigCommerce, 2020e).

For example, LARQ, a seller of selfcleaning water bottles, recently launched its website using BigCommerce as an e-commerce platform and a user-friendly interface using React software solutions, (BigCommerce, 2020d) gaining more control over content.

9. Widespread use of video content in the field of e-commerce.

In 2019, video content was shown to increase the conversion rate of e-commerce businesses: $62 \%$ of consumers said they watch product reviews before buying. Streaming video on the home page can also attract the attention of customers (Builderfly, 2020). 
Using podcasting and short video content to increase opportunities for customers to learn about e-commerce brand products and services, better meet customer needs and increase their purchases.

10. The use of service subscriptions and product information messages force customers to return to interacting with an e-commerce company.

Subscriptions have a number of benefits for e-commerce retailers because they make it easier to forecast consumer needs and allow you to interact with customers for long-term benefit. This is evidenced, in particular, by the successful experience of using a paid subscription Amazon Prime from the world's largest online marketplace Amazon.

At the same time, experts believe that consumers are potentially increasingly aware of the impact of several subscription services on their budgets, so they may be more legible in the future. Retailers implementing this business model need to know what makes their specific subscription mandatory.

11. Implementation of solutions in the field of environmental protection is an effective way to improve the management of e-commerce enterprises.

Brands that improve their performance by focusing on the need to preserve the environment have a stronger influence on customer decisions. Management in this area involves the use of solutions such as:

- use of biodegradable packaging;

- paperless approach to ordering;

- extensive use of secondary raw materials, in particular, for packaging products sold by the enterprise;

- energy saving, etc.

For example, 4ocean (2020) has made this approach a fundamental part of its business model. They offer to buy bracelets or other products made from waste removed from the world's oceans, as well as using environmentally friendly packaging from EcoEnclose to deliver their products.

12. E-commerce businesses are optimizing their digital conversion strategy.

Winning the competition in e-commerce means not only attracting more potential customers to the site, but also converting them as soon as they appear. Conversion optimization is becoming an increasingly serious issue in today's business environment as companies strive to effectively customize their product pages and ensure that their products stand out in all areas of multi-channel marketing. This may include dynamic advertising on Facebook, advertising on Google purchases or digital marketing efforts (BigCommerce, 2020c). As more business companies move online and existing online businesses hone their offerings, one factor to consider is changing customer expectations.

\section{Conclusions.}

Thus, the world experience in managing e-commerce enterprises as subjects of innovative entrepreneurship shows the existence of certain management trends that determine the nature of market transformations and the activity of companies in changing ways and methods of doing business and managing enterprises to adapt to these transformations. Such management trends are discussed above. At the same time, such trends can serve as a basis for improving the management of e-commerce enterprises in Ukraine, which should be based, according to the author, on the following, presented in Figure 1, ambush.

Given the recorded trends, it can be argued that the future of e-commerce and the future management of enterprises operating in this area will be fundamentally different from the current situation. But the latest management technologies, emerging from the need to adapt to technological change and changes in consumer needs, have not yet proven their effectiveness at the level of, for example, small and medium enterprises, but are actively implemented and tested by market leaders. 
Features of world experience that determine the need of e-commerce enterprises of Ukraine to focus on the implementation of the latest technological solutions and modern management approaches that create more opportunities for:<smiles></smiles>

Directions for improving the activities of e-commerce enterprises in Ukraine based on world experience reducing the duration of interaction when choosing and placing an order and delivery times

increase the consumer's choice (payment options, delivery methods, product range, etc.)

reduction of transaction and overhead costs of the e-commerce enterprise

(1)

\begin{tabular}{|l|l|}
\hline $\begin{array}{l}\text { Implementation of augmented reality } \\
\text { solutions }\end{array}$ \\
\hline $\begin{array}{l}\text { Implementation of solutions in the } \\
\text { field of voice search } \\
\text { Implementation of solutions in the } \\
\text { field of artificial intelligence }\end{array}$ \\
\hline $\begin{array}{l}\text { Implementation of solutions in the } \\
\text { field of creating a personalized offer } \\
\text { to provide individual consumer expe- } \\
\text { rience }\end{array}$ \\
\hline $\begin{array}{l}\text { Implementation of solutions in the } \\
\text { field of using chatbots in the process } \\
\text { of interaction with consumers }\end{array}$ \\
\hline $\begin{array}{l}\text { Implementation of solutions in the } \\
\text { field of mobile technologies in the } \\
\text { field of e-commerce }\end{array}$
\end{tabular}

\section{Fig. 1. Directions for improving the activities of e-commerce enterprises in Ukraine on} Source: compiled by the author. increasing the speed of interaction with customers, 


\section{References}

4ocean (2020), "We are a purpose-driven business with a mission to end the ocean plastic crisis", available at: https://4ocean.com/ (Accessed 2 February 2020).

Abraham, M., Archacki, R., González, J. E., Fanfarillo, S. and Van Kerckhove, J.-F. (2020), “The next level of personalization in retail”, available at: https://www.bcg.com/publications/2019/next-level-personalizationretail.aspx (Accessed 2 February 2020).

BigCommerce (2020a), "Ecommerce trends that are powering online retail forward", available at: https://www.bigcommerce.com/blog/ecommerce-trends/\#14-ecommerce-trends-leading-the-way (Accessed 3 February 2020).

BigCommerce (2020b), "How personalization can reduce ecommerce bounce rates by 20-30\%", available at: https://www.bigcommerce.com/blog/bounce-rates/\#what-is-a-bounce-rate-on-an-ecommerce-website

(Accessed 2 February 2020).

BigCommerce (2020c), "How to reach the right audience with digital marketing", available at: https://www.bigcommerce.com/blog/how-to-reach-the-right-audience-with-digital-marketing/ (Accessed 3 February 2020).

BigCommerce (2020d), "LARQ recharges reusable water bottle industry with Google Pay and headless commerce", available at: https://www.bigcommerce.com/case-study/larq/ (Accessed 5 February 2020).

BigCommerce (2020e), "Understanding the rise of PWAs in ecommerce: How brands can benefit from a progressive frontend", available at: https://www.bigcommerce.com/blog/pwa/ (Accessed 4 February 2020).

Builderfly (2020), “5 reasons ecommerce product videos will increase sales”, available at: https://www.builderfly.com/5-reasons-ecommerce-product-videos-will-increase-sales (Accessed 5 February 2020).

Burrow (2020), "The luxury couch for real life”, available at: https://burrow.com/our-story (Accessed 3 February 2020).

Business Insider Intelligence (2016), “80\% of businesses want chatbots by 2020 ”, available at: https://www.businessinsider.com/80-of-businesses-want-chatbots-by-2020-2016-12 (Accessed 3 February 2020).

Enterprise Europe Network (2018), “A guide to e-commerce in Europe”, available at: https://een.ec.europa.eu/sites/default/files/een_guide ecommerce_2018.pdf (Accessed 2 February 2020).

Kabaivanov, S. and Markovska, V. (2019), "Making a difference: accounting for the impact of management decisions in environmental management", Scientific annals of economics and business, vol. 66, no. 2, pp. 131-139, doi: http://dx.doi.org/10.47743/saeb-2019-0014

Kensium (2020), "We provide end-to-end commerce solutions", available at: https://www.kensiumsolutions.com/ (Accessed 4 February 2020).

Kinsella, B. (2019), "Loup Ventures says $75 \%$ of U.S. households will have smart speakers by 2025, Google to surpass Amazon in market share", available at: https:/voicebot.ai/2019/06/18/loup-ventures-says-75-of-us-households-will-have-smart-speakers-by-2025-google-to-surpass-amazon-in-market-share/ (Accessed 2 February 2020).

Kuksa, I., Hnatenko, I., Orlova-Kurilova, O., Moisieieva, N. and Rubezhanska, V. (2019), "State regulation of innovative employment in the context of innovative entrepreneurship development”, Management Theory and Studies for Rural Business and Infrastructure Development, vol.41, no. 2, pp. 228-236, doi: https://doi.org/10.15544/mts.2019.19

Loesche, D. (2018), “Mobile E-commerce is up and poised for further growth", available at: https://www.statista.com/chart/13139/estimated-worldwide-mobile-e-commerce-sales/ (Accessed 4 February 2020).

Malerba, F. and McKelvey, M. (2019), "Knowledge-intensive innovative entrepreneurship", Foundations and Trends in Entrepreneurship, vol. 14, no. 6, pp. 555-681, doi: http://dx.doi.org/10.1561/0300000075

Molnár, B. and Mattyasovszky-Philipp, D. (2019), “Cognitive information systems - artificial intelligence \& management decisions”, 12th IADIS International Conference Information Systems, University of Applied Science, Utrecht, Netherlands, April 11-13, 2016, pp. 290-294.

Natori (2020), “Explore the brands”, available at: https://www.natori.com/ (Accessed 3 February 2020). 
Symakov V.S. Management decisions on modernization of e-commerce enterprises as subjects of innovative entrepreneurship

Omale, G. (2019), "Gartner says 100 million consumers will shop in augmented reality online and in-store by 2020", available at: https://www.gartner.com/en/newsroom/press-releases/2019-04-01-gartner-says-100million-consumers-will-shop-in-augme (Accessed 2 February 2020).

Osman, M. (2020), “Ecommerce statistics for 2020 - chatbots, voice, omni-channel marketing”, available at: https://kinsta.com/blog/ecommerce-statistics/ (Accessed 3 February 2020).

Semerádová, T. and Weinlich, P. (2019), Impacts of online advertising on business performance, IGI Global, Pennsylvania, USA, 262 p. doi: http://doi.org/10.4018/978-1-7998-1618-8

Цей твір ліцензовано на умовах Ліцензії Creative Commons «/з Зазначенням Авторства - Некомерційна 4.0 Міжнародна» (CC BY-NC 4.0).

This is an open access journal and all published articles are licensed under a Creative Commons "Attribution-NonCommercial 4.0 International" (CC BY-NC 4.0). 